\title{
Municípios in the Time of Covid-19 in Brazil: Socioeconomic Vulnerabilities, Transmission Factors and Public Policies
}

\author{
Mireille Razafindrakoto ${ }^{1}$ (D) François Roubaud ${ }^{1}$ (D) . João Saboia ${ }^{2}$ (D) . \\ Marta Reis Castilho ${ }^{2}$. Valeria Pero ${ }^{2}$ D
}

Accepted: 21 October 2021 / Published online: 11 November 2021

(c) European Association of Development Research and Training Institutes (EADI) 2021

\begin{abstract}
This paper aims at identifying the Covid-19 infection and mortality risk factors in Brazil during the pandemic's first wave. Three groups of variables are considered: socioeconomic and health vulnerabilities, factors related to the virus transmission channels (mobility and density) and the effects of the policy responses. The analysis at the level of all 5,570 municipalities, drawing on a matching of different statistical and administrative databases, returns three main results. First, structurally vulnerable populations are hardest hit-non-white, poor, in poor health, favela residents and informal workers-showing the impact of socioeconomic inequalities. Second, we highlight some policy repercussions. The Auxilio Emergencial (emergency cash transfer) has had a mitigating effect in communities with relatively more informal workers. Finally, Covid-19 has hit hardest in municipalities that are more pro-Bolsonaro. The president's rhetoric and attitudes may have prompted his supporters to adopt more risky behaviour, suffer the consequences and infect others.
\end{abstract}

Keywords Brazil $\cdot$ Covid-19 $\cdot$ Informality $\cdot$ Public policy $\cdot$ Socioeconomic inequality $\cdot$ Bolsonaro effect $\cdot$ Municipality

Mireille Razafindrakoto

razafindrakoto@dial.prd.fr

François Roubaud

roubaud@dial.prd.fr

João Saboia

saboia@ie.ufrj.br

Marta Reis Castilho

castilho@ie.ufrj.br

Valeria Pero

vpero@ie.ufrj.br

1 Institut de Recherche pour le Développement, LEDa-DIAL Research Unit, PSL, Université Paris-Dauphine, 4 rue d'Enghien, 75010 Paris, France

2 Institute of Economics, Federal University of Rio de Janeiro, Avenida Pasteur, 250,

Rio de Janeiro 22290-240, Brazil 


\section{Résumé}

Cet article cherche à identifier les facteurs de risque de contracter le COVID-19 et d'en mourir durant la première vague de la pandémie au Brésil. Trois groupes de variables sont considérés : les facteurs socio-économiques et sanitaires, ceux liés aux canaux de transmission du virus (la mobilité et la densité) et les effets des réponses politiques. Réalisée sur l'ensemble des 5570 municipalités et basée sur l'appariement de différentes bases de données statistiques et administratives, l'analyse fait ressortir trois principaux résultats. En premier lieu, les populations structurellement vulnérables sont les plus touchées - non-blancs, pauvres, de santé précaire, habitants des favelas, informels - renforçant l'effet des inégalités socioéconomiques. En deuxième lieu, nous mettons en évidence l'influence des politiques. L'Auxilio emergencial (transfert monétaire d'urgence) a un effet atténuateur dans les localités ayant relativement plus de travailleurs informels. Enfin, le CoVid-19 fait plus de ravages dans les municipalités plus favorables à Bolsonaro. Le discours du président induit ses partisans à adopter plus souvent des comportements à risque et à en subir les conséquences.

\section{Introduction}

In October 2020, Brazil ranked among the countries hardest hit by Covid-19 in terms of numbers of deaths and in terms of numbers of confirmed cases. Our study presents information on the progression of the pandemic during its first wave in Brazil to help understand the outcomes of response policies implemented or to be promoted. Although epidemiological studies are on the rise, studies of the socioeconomic factors of Covid-19 transmission remain thin on the ground. This situation is especially problematic in that although individuals' biological characteristics play a role, they are not the only factors in play. Their impacts are highly dependent on their interaction with individual and collective human behaviour. A better understanding of the pandemic's progression and effectiveness of response policies can only be gained by considering these two dimensions together. Such is the contribution that this paper intends to make.

The purpose of our study is to identify the Covid-19 infection and mortality risk factors. Three groups of variables are considered: socioeconomic and health vulnerabilities, factors related to the virus transmission channels (mobility and density) and the effects of the policy responses (measures and political factors). The analysis at the level of all the country's 5,570 municipalities (municípios) draws on a wide range of statistical and administrative databases.

This municipality approach, which rounds out the individual-level analyses, has a number of advantages, mainly that: (i) as regards data availability, first, it is the only approach to guarantee an exhaustive analysis of all corresponding geographical localities in the country; and second, socioeconomic surveys do not count deaths, while administrative health records are poor socioeconomic descriptors; (ii) the effects of the pandemic are manifested not only at the individual level, but also at the collective level; and (iii) most importantly, disease response policies are conducted at municipal level. 
The first part of the paper conducts a brief review of the literature on the subject. The second presents an overview of the Brazilian context, discussing the epidemiological situation and the policies implemented. The third details the methodological approach, presents the data and provides initial descriptive statistics. The fourth discusses the results and the dynamics since the start of the pandemic. Finally, the conclusion focuses on learnings and outlook.

\section{Socioeconomic and Political Risk Factors: A Brief Review of the Literature}

The growing literature on Covid-19 is very recent, as is the pandemic (Brodeur et al. 2020). The literature is essentially epidemiological and, to a lesser extent, economic. We present an overview of selected available socioeconomic analyses on Brazil and a selected set of papers from the international literature that share our methodological approach. Among the studies on Brazil, we first review the main results of the analyses focussing on the socioeconomic dimensions of actual and potential Covid19 incidence before looking into the part played by political factors in the pandemic's evolution. Where some interesting papers have focussed on specific regions, ${ }^{1}$ we have opted for an analysis covering the entire territory and capturing the country's diversity.

A first set of studies investigates the socioeconomic characteristics of people infected by Covid-19. Using different types of data, and through various approaches, they converge to show the importance of socioeconomic factors. Hallal et al. (2020) use individual data from a vast testing programme of 55,000 randomly selected participants in 133 cities nationwide. Their serological results suggest, among other things, a case underreporting figure of some $70 \%$. The socioeconomic data collected show that the virus infects different population categories. In terms of ethnicity, indigenous people (Índios), followed by blacks (Afro-descendants or Pretos) and browns (mixed race or Pardos), are found to have much higher seroprevalence rates than whites $(6.3,3.6,3.4$ and 1.4 , respectively). Prevalence rates by sex return different results for the two tested periods, and in terms of age, the highest rate is found at between 30 and 59 years old. Living conditions indicators highlight the frail health of the poor, with prevalence increasing with the number of inhabitants per household and decreasing with household wealth.

\footnotetext{
1 For papers on the socioeconomic factors of Covid-19 infections and deaths in specific cities and states, see Miranda et al. (2020), De Negri et al. (2020), Silveira et al. (2020) and Instituto Polis (2020). One recent paper-Braga Ribeiro et al (2021) — conducted a study on the individual and collective (by district) characteristics of Covid-19 deaths in São Paulo. The paper finds similar risk factors as other papers, but goes on to show, from a comparison of race information with the characteristics of the health facilities where deaths occurred, that the higher mortality of black and mixed race populations from Covid-19 could be a consequence of discrimination and barriers to healthcare access for these populations.
} 
Baqui et al. (2020) set out to identify the individual risk factors associated with Covid-19 mortality using the national flu database. ${ }^{2}$ It provides a certain number of socioeconomic characteristics on each patient admitted to hospital (age, sex, region and skin colour typology) and comorbidities. Despite there being 19,940 patients in the database who tested positive as at 4 May 2020, the non-response rate was so high that the analysis ultimately covered a sample of just 6,882 patients. In addition to the classic risk factors of age and comorbidity, the Cox model estimation produces findings on risk by skin colour and region. Other things being equal, Afrodescendants and mixed race populations have a $45 \%$ and $32 \%$ higher risk of dying than white people.

Using the Ministry of Health's "Síndrome Respiratória Aguda Grave" (severe acute respiratory infection) database, Batista et al. (2020) analyse the socioeconomic dimensions of Covid-19 deaths and infections at national level. ${ }^{3}$ The study uses simple cross tables to show that the case-fatality rate increases with age. This rate is also higher among indigenous people, afro-descendants and mixed race populations, as well as among people with a low level of education. Using Human Development Index information by municipality, the authors find that the case-fatality rate is higher in the poorest municipalities.

Rocha et al (2021) cover a quite wide range of factors influencing the number of Covid-19 deaths, measured by an age-adjusted death indicator and physical distancing. The study considers socioeconomic factors (including housing conditions, informality, income and education) and health vulnerability factors (hospital units and medical assistance). The main conclusion to emerge from the correlation and regression analysis for the period between March and October 2020 is the importance of social vulnerability over other factors, especially health factors. Although the data on hospital and health services are very detailed, the analysis of social vulnerability is based on a synthetic composite index built on quite a small set of variables. The entire analysis is conducted essentially at state level, although it does use some municipal-level data.

Another set of studies takes a different angle, focussing on vulnerability and risk factors using individual-level data. Nassif-Pires et al. (2020a, b) calculate the risks of infection and death based on the three dimensions of vulnerability: the "social" dimension, associated with working and housing conditions; access to health services; and medical risks. ${ }^{4}$ An analysis of vulnerability indices constructed for different population categories finds that the risks appear to be higher among indigenous people, Afro-descendants and mixed race populations. In general, women are less vulnerable, although Afro-descendant, mixed race and indigenous women present higher risks than the population average as a whole. Risks decrease as income and

\footnotetext{
2 "Sistema de informação de vigilância epidemiológica da gripe" (SIVEP-Gripe) published by the Brazilian Ministry of Health (http://plataforma.saude.gov.br/coronavirus/dados-abertos/).

3 The authors analyse a sub-sample of 29,333 individuals who recovered or died from Covid-19 out of a sample of 43,906 confirmed cases in the abovementioned database between March and May 2020.

4 The medical risks considered and covered by the medical literature are: being over 60 years of age and diagnosed with different chronic diseases. The authors used individual data from the "Pesquisa Nacional de Saúde” (National Health Survey, IBGE 2013).
} 
education increase. In terms of medical characteristics, comorbid conditions are found more among the less educated population, which adds force to the higher risks found for the disadvantaged populations.

In a similar work, Nunes et al. (2020) analyse health, work and housing vulnerabilities in tandem. The authors use the same sources as the previous study, but with additional variables and a different methodology (Probit model estimates). Economic vulnerability is captured by labour market informality. Housing vulnerability covers access to water and sanitation, household density, type of construction and the existence of household waste collection. Analysis by level of education, age and federal state shows that while the elderly are more vulnerable in terms of health, young people are not spared. Almost half of the population under 60 years old present at least one health risk factor and are the most vulnerable economically. Indeed, these characteristics often overlap. The analysis by federal state turns up significant regional disparities. Greater housing vulnerability in the country's poorest regions compounds economic vulnerability and the fragile health systems in these same regions.

In the same vein, Tavares and Betti (2020) construct two specific indices: the "Covid-19 prevention index" and the "Covid-19 recovery index". They use the Alkire-Foster (AF) methodology for multidimensional poverty measures and a fuzzy set approach. Results suggest that at least $15 \%$ and $13 \%$ of the Brazilian population have strong limitations on their preventing and recovering from Covid-19 due to social conditions and the healthcare system. The analysis based on the proposed indexes also reveals huge inequalities among states and among ethnic groups, with non-white people more at risk of infection and recovery difficulties. The geography of prevention and recovery vulnerabilities coincides with the geographies of the Covid-19 mortality rate and monetary poverty, confirming that both monetary and non-monetary measures are relevant in mitigating the effects of the pandemic.

Turning to political factors, two main papers address the influence of President Bolsonaro's behaviour on the evolution of the pandemic. First, Argentieri Mariani et al. (2020) investigate the effect of President Bolsonaro's sceptical attitude to the Covid-19 pandemic. The authors conduct a difference-in-difference analysis of both the pro-Bolsonaro municipalities (those where the president won more than $50 \%$ of the total votes in the first round of the 2018 election) and the other municipalities, before and after the demonstrations ${ }^{5}$ of 15 March 2020. Pro-government demonstrations were held in 250 of the 1,050 municipalities that registered at least one case of Covid-19 prior to 15 April 2020. Several indicators of the impact of Covid-19 are tested (including excess hospitalisations and excess mortality). This natural experiment shows that the municipalities where demonstrations were held registered more hospitalisations and deaths than the others. The authors believe that this effect is due both to people gathering at the demonstrations and laxer attitudes to social distancing in keeping with the president's rhetoric and position.

\footnotetext{
5 These pro-government demonstrations were held by the president's supporters following growing criticism of and dissatisfaction with his rhetoric and attitude.
} 
Secondly, Ajzenman et al. (2020) also set out to assess the importance of the president's rhetoric. They estimate a fixed-effects panel model for the Brazilian municipalities. The results show that, in pro-Bolsonaro municipalities (also identified by the 2018 election results), people's mobility increased consistently in the week following the president's actions and words to make light of the impacts of the pandemic and discourage compliance with social distancing. This effect is stronger in municipalities with a significant local media presence, a high number of Twitter accounts (a social network used extensively by the president) and a high proportion of evangelists.

Lastly, a recent paper focuses on the acceleration of cases and deaths during the first quarter of 2021 (Rache et al. 2021). Based on a descriptive analysis of the number of deaths, the extent of social distancing and the 2018 vote for Bolsonaro, the authors find a positive correlation between the vote for Bolsonaro and Covid-19 deaths. Simplicity of the exercise aside, it is interesting to note that the "Bolsonaro effect", as we call it subsequently in this paper, still appears to hold in 2021 .

At the international level, if we look at studies closer to ours in terms of method and research questions, McLaren (2020) analyses racial disparities in Covid-19 mortality at U.S. county level. The author takes a sample of 3,140 counties, representing 322 million U.S. residents, and compares mortality data (as of 19 May 2020) with census data to show that the proportion of deaths is closely correlated with the proportion of African Americans (and First Nations) in the county, and that this correlation is robust to the introduction of control variables such as education, income, type of job (occupation, commuting and teleworking compatibility) and health insurance. Brown and Ravallion (2020) conduct a more in-depth analysis of the impact of poverty and inequality on infection rates in the US at county level. They also find a strong race effect whose predominance is illustrated by the fact that income inequality and poverty effects vanish when they control for the share of Black Americans. Finally, Brandily et al. (2020) undertake an ambitious analysis at municipality level in France. They show that the epidemic disproportionately affects the poorest municipalities. Poor housing conditions (especially overcrowding) and occupational exposure appear to be the most likely transmission mechanisms. This work has many advantages over other studies. First, the variable of interest is not the number of deaths recorded, with their unanimously recognised biases, but excess mortality over the number of deaths in the previous year. Second, they draw on a combination of different data sources on the 30,000 French municipalities. Third, they take a quasi-experimental (triple difference) approach to estimate the causal impact of the pandemic.

To conclude this brief literature review, almost all existing studies on Brazil find that vulnerability - estimated or observed (by infection or death rate)—is higher for more fragile populations from several points of view. Studies are unanimous that non-whites are harder hit by Covid-19. Evidence of the most fragile groups' greater vulnerability to Covid-19 is also highlighted in three other dimensions: economic conditions (income and work); housing — with the two being linked—; and level of education. The only aspect on which the studies are not unanimous concerns the differences between men and women. 
This study seeks to improve on the abovementioned analysis of Brazil with a wide array of variables to cover the multiple dimensions of the factors affecting the progression of the pandemic during its first wave, such as socioeconomic, demographic, cultural (political and religious) and economic policy-related factors. Conducted at municipality level and at different dates to monitor the impact of each factor over time, this analysis provides insights to complement existing studies.

\section{The Brazilian Context}

\section{The Epidemiological Situation}

Brazil is among the countries hardest hit by the Covid-19 pandemic. In October 2020, official sources reported over 150,000 deaths and over 5,000,000 confirmed cases. So, in absolute numbers, Brazil is ranked among the three most affected countries in the world with the United States and India. These figures should be viewed with caution due to underestimation (of the number of cases) and poor data quality in most of the world's countries. Yet Brazil's particularly low testing rate would appear to bear out this ranking. ${ }^{6}$ When ranked as a ratio of the country's population, however, Brazil is not among the hardest hit by the pandemic even though it remains high on the board with 710 deaths and 24,000 confirmed cases per million inhabitants (Table 1).

Figure 1 shows the trend in the daily and cumulative numbers of confirmed cases and deaths. Both figures show numbers still running high, although on the downturn, through to October. Following a sharp rise in the first three months (March to May), the number of deaths plateaued. From late May to mid-August, the death toll stabilised at a high level of around 1,000 per day before gradually declining through to the end of October, albeit still at over 400 deaths per day on average. Confirmed cases reached a first plateau of some 25,000 cases per day in early June. This number rose to around 37,000 in the first half of July before peaking at 46,000 on average in late July and then falling from that date on. By early October, the moving average stood at some 25,000 cases per day. ${ }^{7}$

\section{Policy Responses}

In terms of policy responses to the coronavirus pandemic, two types of measures have been taken worldwide: (i) public health measures-called non-pharmaceutical interventions (NPIs) - to reduce contact rates in the population and thereby the transmission of the virus; and (ii) economic policies to cushion the health crisis's adverse impacts on households and businesses.

\footnotetext{
6 See Sect. 3 for a discussion of health and economic policies adopted.

7 A new rise in the number of cases in November signalled the second wave of the pandemic for Brazil.
} 
Since the announcement of the Covid-19 pandemic by the World Health Organization on 11 March 2020, "social distancing" has been one of the NPIs recommended to control the spread of the new coronavirus. National governments worldwide have defined actions to implement NPIs such as the suspension of non-essential businesses, self-isolating at home, teleworking and movement restrictions in cities.

In Brazil, President Bolsonaro's main response has been to dismiss the virus as a danger, calling it a "little flu" (gripezinha) and discouraging social distancing and lockdown measures on the grounds of their negative economic repercussions for the country (Ortega and Orsini 2020; Barberia and Gómez 2020). Much like President Trump's handling of the pandemic crisis, the Brazilian government's actions bear the marks of a particular context that features a combination of a lack of a comprehensive NPIs and domestic political crisis within the government (Lasco 2020; Malta et al. 2020). Such disarray at central public administration level sows confusion and negatively impacts the population's compliance with mitigation measures (Ajzenman et al. 2020; Ricard and Medeiros 2020). Given the President of the Republic's denialist stance and the lack of united, coordinated action by the Ministry of Health at national level, subnational government (state governors and city mayors) has taken the lead in tackling the pandemic crisis (Fonseca et al. 2020). ${ }^{8}$

In March 2020, all Brazilian states closed their schools and at least part of nonessential businesses and suspended social events. In April, the states started to develop plans to ease their social distancing measures. These plans had been adopted by 21 states by the end of July 2020, with broad diversity in terms of format, technical criteria and transparency, as well as the number of municipalities taking up their state's plan (Pereira et al. 2020; Moraes et al. 2020). For instance, the State of Minas Gerais had a plan to ease the NPIs based on technical criteria (new cases, deaths and hospitalisation capacity), but less than two-thirds of the municipalities followed the plan. De Souza Santos et al. (2020) offer a spatial and temporal dataset on adoption and easing of various NPIs in Brazilian municipalities that reveals asynchronous actions and a total lack of coordination between neighbouring cities. The performance and success of NPIs have been hindered by the absence of an adequate testing and tracking policy (Benitez et al. 2020; Moraes et al. 2020). These lockdown measures unleashed an economic crisis unprecedented in recent history and revealed huge socioeconomic inequalities in capacities to cope with the uncertainties of the pandemic.

Emergency social policies to guarantee basic income for the most fragile populations and policies to support workers and businesses are key to prevent the pandemic crisis from deepening socioeconomic inequalities and poverty. The Brazilian government introduced a raft of measures to tackle the negative effects of the pandemic. The federal government adopted two sets of emergency economic policy measures (Silveira 2020; Waltenberg et al. 2020): (i) tax measures to guarantee family incomes, support businesses and provide financial assistance to states and

\footnotetext{
${ }^{8}$ In fact, the Brazilian Supreme Court ruled in April 2020 that city mayors and state governors were autonomous in their decisions concerning the pandemic.

http://portal.stf.jus.br/noticias/verNoticiaDetalhe.asp?idConteudo=441447\&ori=1.
} 
Table 1 Top ten countries hit by Covid-19 worldwide (14 October 2020)

\begin{tabular}{llllc}
\hline & Deaths & $\begin{array}{l}\text { Mortality rate (per } \\
\text { million inhab.) }\end{array}$ & Confirmed cases & $\begin{array}{l}\text { Infection rate (per } \\
\text { million inhab.) }\end{array}$ \\
\hline United States & 221,431 & 668 & $8,126,349$ & 24,510 \\
Brazil & 151,161 & 710 & $5,117,825$ & 24,028 \\
India & 111,272 & 80 & $7,301,804$ & 5,276 \\
Mexico & 84,420 & 653 & 825,340 & 6,382 \\
UK & 43,155 & 635 & 654,644 & 9,629 \\
Italy & 36,289 & 600 & 372,799 & 6,168 \\
Peru & 33,419 & 1,010 & 853,974 & 25,799 \\
Spain & 33,413 & 715 & 937,311 & 20,045 \\
France & 33,037 & 506 & 779,063 & 11,928 \\
Iran & 29,349 & 348 & 513,219 & 6,088 \\
World & $1,094,386$ & 140 & $38,640,757$ & 4,957 \\
\hline
\end{tabular}

Source: "Covid-19 Coronavirus Pandemic," Worldometer, last updated 14 October 2020, https://www. worldometers.info/coronavirus

Confirmed Cases

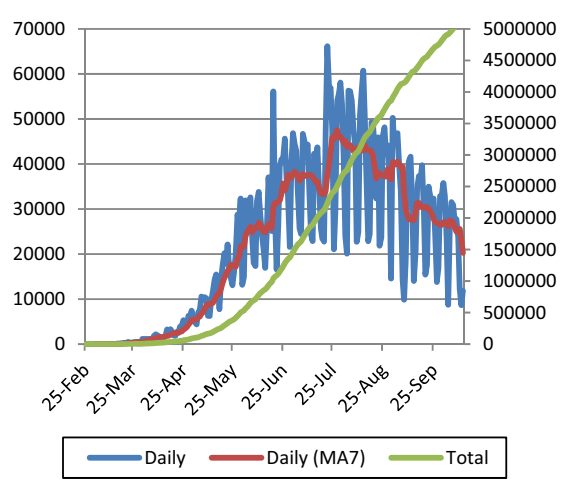

Deaths

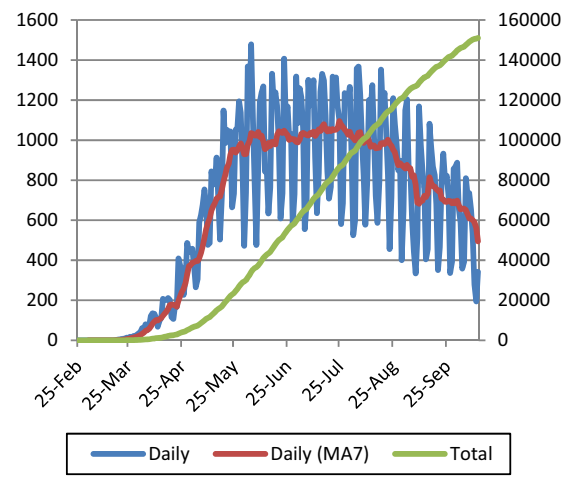

Source: Ministry of Health/Fiocruz (https://bigdata-covid19.icict.fiocruz.br/, accessed 13 October 2020); authors' calculations.

Note: MA7: Moving Average (last seven days). Total on the right-hand scale.

Fig. 1 Confirmed cases and deaths due to Covid-19 (13 October 2020)

municipalities; and (ii) liquidity support and regulatory capital measures to ensure the stability of the financial system and expand the credit supply.

Focussing on the first set of measures, which directly impact the population, the Brazilian government launched an emergency plan to guarantee a minimum income for the most disadvantaged groups. The Emergency Aid for People in Vulnerable Situations (Auxílio Emergencial a Pessoas em Situação de Vulnerabilidade (AE)), the most popular measure during the pandemic, was launched in April 2020. Following a strong civil society campaign and intense pressure from Congress, the federal 
government introduced an Emergency Basic Income of $\mathrm{R} \$ 600$ per month, instead of the $\mathrm{R} \$ 200$ initially proposed by the government. ${ }^{9}$ The cash transfer was basically intended for informal workers in precarious situations. Following the three-month experiment, the government opted to extend it through to August 2020. In September, the benefit was then extended again through to December 2020 at the reduced sum of $\mathrm{R} \$ 300$. This AE cash transfer programme represented a substantial amount in terms of public expenditure, far above equivalent programmes in Latin American countries (World Bank 2020).

In April 2020, the Brazilian government launched another programme to guarantee income in the shape of the Emergency Benefit to Maintain Employment and Income (Benefício Emergencial para Preservação do Emprego e da Renda-BEM) for low-income formal employees (Hecksher and Foguel 2020). This programme introduced a proportional reduction in working hours with wages paid at $25 \%, 50 \%$ or $70 \%$ of the full wage for three months or temporary suspension of the employment contract and payment of emergency benefit for two months, later extended through to December 2020. The government tops up employee incomes based on the amount of unemployment benefit to which they would be entitled.

Despite design and implementation problems with the Emergency Aid and Emergency Benefit Programmes, they have been quite successful at protecting the earnings of low-income workers (Bartholo et al. 2020; Carvalho 2020a, b; Costa and Reis 2020; Mattei and Heinen 2020). As at 31 August 2020, 67.2 million people were covered by the Emergency Aid Programme with $84 \%$ receiving R $\$ 600$ in benefit and $16 \%$ receiving $\mathrm{R} \$ 1200 .{ }^{10}$ As at 31 July 2020, 12.4 million Emergency Benefit Programme work agreements had been signed, with employees receiving an average monthly benefit of $\mathrm{R} \$ 863$. $^{11}$

The Brazilian labour market was already seriously struggling prior to the pandemic and, despite the relative success of the two programmes, the labour market slumped throughout 2020. The early months of Covid-19 saw a huge outflow of people from the labour force, mainly from the informal sector due to movement restrictions. The increase in the unemployment rate was consequently relatively small. The relaxation of social distancing measures subsequently brought a slight economic recovery and the return of part of the labour force. However, perhaps the most striking labour market figure in the first six months of the pandemic was the 12 million job losses, slashing the number of employed from 94 to 82 million. $^{12}$

Central government also introduced Financial Aid for States, Municipalities and the Federal District, another important measure as the subnational governments were hard hit by the decrease in tax revenues, the increase in spending on hospitals and welfare, and the increase in Ministry of Health spending (Silveira 2020).

\footnotetext{
${ }^{9} \mathrm{US} \$ 1=\mathrm{R} \$ 5.5$. This value corresponds to approximately $60 \%$ of the national minimum wage $(\mathrm{R} \$ 1045)$.

${ }^{10}$ Lone-parent families headed by women received R \$1200. See https://aplicacoes.mds.gov.br/sagi/data

11 https://portal.tcu.gov.br/imprensa/noticias/mais-de-12-milhoes-de-trabalhadores-foram-beneficiadospor-programa-emergencial.htm

12 See Lameira (2021) and Carvalho (2020a, 2020b) for a more detailed analysis of labour market performance before and during the pandemic.
} 
Brazil has one of the largest public health systems in the world (Sistema Único de Saúde; SUS), with good capillarity in the municipalities, serving around $75 \%$ of the Brazilian population with the remaining $25 \%$ covered by private health insurance (Paim et al. 2011; Benitez et al. 2020). The system holds a set of primary care services, notably those comprised in the family health strategy ${ }^{13}$ and the basic health units, which played an important role in initial assistance and guidance to the population on Covid-19 pandemic. SUS holds also medium and high complexity care services which availability and quality vary strongly across the country. The pandemic revealed the scarcity of healthcare resources and laid bare deep inequalities, not only between public and private healthcare, but within SUS itself and in the difference in the supply of ICU beds between municipalities and regions in the country (Rache et al. 2021; Rocha et al. 2021).

However, the abovementioned Emergency Aid for People in Vulnerable Situations and the Emergency Benefit to Maintain Employment and Income were the main measures taken by the federal government to mitigate the impacts of Covid-19. Through to September 2020, they accounted for $62 \%$ of the 2020 expenditure prevision to fight the pandemic (Table A2 in Online Appendix). ${ }^{14}$

The IMF (2020) estimates Brazil's federal expenditure to fight Covid-19 at 10\% of the country's GDP. Brazil's spending is lower than the developed countries-particularly Germany, Italy, Japan and the UK-but exceeds most of the other developing and emerging economies.

The government's emergency income guarantee plan in response to the pandemic crisis appears to have reached the most vulnerable in large numbers, narrowing inequalities in per capita household income (Carvalho 2020a, b; Menezes-Filho et al. 2021). It is worth mentioning that the effort made to identify and register Emergency Aid beneficiaries has laid a building block for the future to facilitate access to large-scale welfare programmes in Brazil.

Despite President Bolsonaro's ambiguous, if not outright hostile attitude, and the Ministry of Health's hesitancy, both economic and public health policy has tended to focus on restricting population movements. However, actual mobility depends not only on policy, but also on the authorities' capacity to enforce the measures and the extent of the populations' support for these measures. Data from Google Mobility and Facebook Movement Range Maps ${ }^{15}$ reveal a sharp and massive drop in mobility in Brazil from 13 to 25 March 2020.

Hereafter, lockdown gradually eased under the dual effect of the relaxation measures and less compliance by the population, albeit without returning to pre-pandemic conditions. Facebook data show that at the height of lockdown (end of March), only $40 \%$ of the population stayed at home all day. This rate fell to $25 \%$ in early October, barely 5 points higher than in the pre-lockdown period (beginning of March).

\footnotetext{
${ }^{13}$ Family health strategy is a preventive strategy in which a multidisciplinary health team follows the household members health and provides basic care services.

14 https://www.tesourotransparente.gov.br/visualizacao/painel-de-monitoramentos-dos-gastos-comcovid-19.

15 https://dataforgood.fb.com/tools/movement-range-maps/
} 
However, this national trend obscures differences observed at municipal level, which Facebook data reveal to be highly diverse.

\section{Methodology, Data and Descriptive Statistics}

The unit of analysis is the municipality, of which there are 5,570 in Brazil. First, it is the smallest administrative entity for which comprehensive data can be gathered on Covid-19, health indicators and the population's socioeconomic characteristics. Second, not only does it cover the entire country, but it can also capture the effects of both collective behaviour (or neighbourhood behaviour) and individual behaviour. We endeavoured in our estimation models to cover a wide spectrum of factors and to be as exhaustive as possible regarding the types of potential variables that might have a direct or indirect effect on infection/mortality rates. Third, many policies are designed and implemented at municipal level, as shown in Sect. 2. These three factors give the municipality approach a number of advantages.

However, it is not without its limitations and results are to be interpreted with due caution. First, the analysis by municipalities cannot be mechanically transposed in terms of individual risks. But at least a significant effect at municipal level guarantees that it is also significant in terms of individual odds. ${ }^{16}$ It can be assumed that individual and municipality approaches generally converge in terms of signs. Otherwise, inverse mechanisms would need to be explained. ${ }^{17}$ The empirical results of the individual approach used in the literature help substantiate our interpretations. Second, the econometric models tested here can be used to estimate the links between the confirmed case and mortality rates and the different factors, corrected for structural effects. Nevertheless, as in many observational data analyses, we identify correlations that do not necessarily point to causality. Cases of reverse causality can occur. For example, it is quite plausible that restriction measures were applied more strictly in municipalities where mortality/infection rates were already higher. It is therefore difficult to disentangle the actual impact of the restriction measures. But the main problem might stem from potentially omitted variables. For example, data availability on health conditions was limited (data on comorbidity prevalence at municipal level would have been useful). Similarly, it would have been interesting to have had detailed indicators per municipality on the reach of NPIs (mask use, social distancing measures, etc.). These different variables may be correlated with other municipality characteristics (geographic location, level of income, health infrastructure, etc.). So the correlation we observe in our model might be due to these omitted variables. Nonetheless, although we do not identify actual causal relationships, the

\footnotetext{
16 If the mortality/contamination rate is different between two population categories (say Poor and NonPoor) at the aggregate level, it should also be different at the individual level (and likewise, if the mortality/contamination rate is the same at the individual level, it should also be the same at the aggregate level).

17 For example, if the municipalities with higher male ratios are harder hit, it does not necessarily mean that males are hardest hit. Women in municipalities where male ratios are high could be most at risk of infection. However, this would imply finding a particular mechanism to support this view.
} 
multiple regression framework we adopt can help policymakers better understand what is correlated and what is not correlated with infection/death rates. It serves to at least rule out certain hypotheses regarding potential causal mechanisms.

\section{Empirical Strategy, Data and Variables}

The fatality rate and rate of confirmed cases are modelled to identify the characteristics of the municipality hardest hit by the pandemic. Given the fact that the data on confirmed cases and deaths are highly non-normally distributed and substantially overdispersed count data, the parameters are estimated by a negative binomial (NB) model ${ }^{18}$ using maximum likelihood.

$$
Y_{i}=\exp \left(a_{0}+\alpha X_{i}+\beta M_{i}+\gamma P_{i}+\delta C_{i}+\delta_{0} T_{i}+u_{i}\right)
$$

$Y_{i}$ represents the dependent variables: either the death rate or the rate of confirmed cases (cumulative counts per 100,000 inhabitants in each municipality $i$ ). ${ }^{19}$ Three blocks of explanatory variables are considered: $X_{i}$ is the vector of sociodemographic/socioeconomic and health vulnerabilities, $M_{i}$ the vector of direct transmission factors at municipal level (individual mobility, density and household characteristics), $P_{i}$ the vector of measures/interventions or political factors, $C_{i}$ the vector of the control variables, and $T_{i}$ the number of days since the first case (exposure time).

Estimation covered different dates in order to check the robustness of the model and see the extent to which the correlation coefficients vary or not over time. We also used panel models to test whether the coefficients that change as a linear function of time might reflect the progression of the epidemic. Two types of specification were tested:

$$
\begin{gathered}
Y_{i t}=\exp \left(a_{0}+\alpha X_{i}+\beta M_{i}+\gamma P_{i t}+\delta C_{i t}+\delta_{0} T_{i t}+u_{i t}\right) \\
Y_{i t}=\exp \left(a_{0}+\alpha X_{i}+h T_{i t} * X_{i}+\beta M_{i}+\gamma P_{i t}+\delta C_{i t}+\delta_{0} T_{i t}+u_{i t}\right)
\end{gathered}
$$

The introduction of the cross effect with the time trend (Eq. 3) takes into consideration that the effect of one factor (whose level is constant) might change over time. Lastly, a state fixed effect regression was also considered to account for any unobservable factors at state level that might impact on the spread of the virus.

The three major groups of explanatory factors are as follow:

(1) The first group $X_{i}$ consists of variables regarding individuals' sociodemographic characteristics (sex, age, race, education and state of health proxied by life expec-

\footnotetext{
18 A naive model with a linear model (OLS) was also considered. Overall, we obtained fairly similar results with the same order of magnitude.

19 The data used are based on bulletins issued by the Ministry of Health compiled by Brasil.io, an independent organisation recognised for the quality of the data that it makes accessible to all types of users. See the robustness checks for more detailed information and a discussion on the quality of the data.
} 
tancy and the number of doctors per 100,000 inhabitants) and socioeconomic characteristics (poverty incidence, GDP per capita and job informality).

(2) The second group $M_{i}$ comprises factors that can accelerate or reduce the transmission of the disease in the municipality: population density, location (urban/ rural), type of settlement (favela) and housing (overcrowding and access to sanitation). In addition to these classic variables, we also included an indicator regarding commuting outside the municipality for professional reasons, a potential factor in the spread of infection.

(3) The third group $P_{i}$ includes variables reflecting certain policies implemented (directly or indirectly): start date of lockdown measures; percentage of President Bolsonaro supporters, assuming these are the people the most reluctant to respect the measures; and percentage of Auxilio Emergencial (AE) beneficiaries among the population interacted with job informality.

We added the number of days since the first case (or exposure time) to these three groups of independent variables, since the pandemic did not start at the same time in the different municipalities. As a control variable $\left(C_{i}\right)$, the test rate was taken to limit the effects of the potential bias or underestimation of the Covid-19 confirmed case data. ${ }^{20}$

The data used come from various sources: census, survey data, administrative records and big data (IBGE 2012, 2013, 2018, 2020; see Table A1 in Online Appendix). The Covid-19 data come from the Ministry of Health's multi-institutional programme to count confirmed cases and deaths. Although the confirmed cases are clearly underestimated (due to a faulty testing policy), deaths are much less so. Unlike many other countries, official Brazilian Covid-19 data are much more reliable than excess mortality estimates (see Robustness Checks section). However, we use excess mortality as a robustness check. Independent variables imply the processing of tens of millions of observations. Here again, Brazil offers a particularly data access-friendly environment. In addition to a recognised public statistics system, the active open government policy gave us access to valuable information on different transparency portals. We also used a dataset on non-pharmaceutical interventions in Brazilian municipalities ${ }^{21}$ combined with Facebook Movement Range Maps to compute our lockdown indicator at municipality level. ${ }^{22}$

\footnotetext{
20 This could be debatable because if the variation in the test rate is not random, but depends on the infection rate, then the test rate should not be used for the correction. The solution used here is to control by the test rate available at state level, assuming that the test rate in each state varies between municipalities according to the infection rate. We also estimated a model considering the test rate as a control variable for the mortality rate. This could be justified since a higher test rate might also make the number of deaths identified as being due to Covid-19 more reliable. This specification does not change the results.

21 De Souza et al. (2020); this dataset is derived from a survey of mayors conducted by the Brazilian Confederation of Municipalities (CNM).

22 We used SARS-CoV-2 non-pharmaceutical intervention data on Brazilian municipalities (https://doi. org/10.5061/dryad.vdncjsxs2) and Facebook data to identify the lockdown start date for each municipality. We did not use the extent of compliance with lockdown measures as an explanatory factor for two reasons: first, because of possible reverse causality (compliance is greater in municipalities with higher death rates); and second, because it would have absorbed the effect of some characteristics, which is precisely what we set out to measure (e.g. informal workers might be harder hit because they cannot comply with the restrictions).
} 


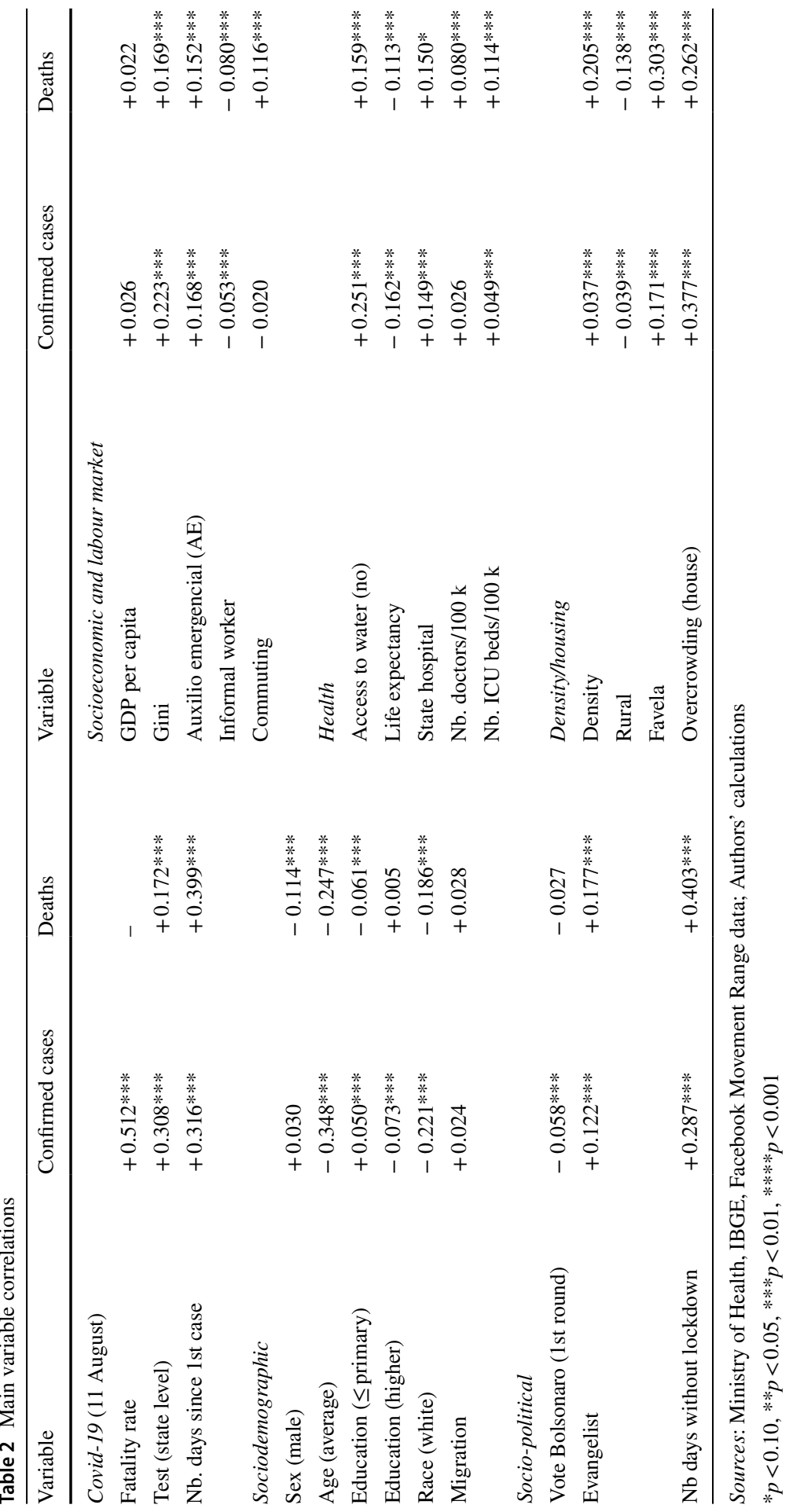




\section{Descriptive Statistics}

As at 11 August 2020, at the peak of the first wave of the pandemic, the average infection and fatality rates per municipality stood at 1,081 and 23 per 100,000 inhabitants, respectively. These rates were hugely dispersed ranging from 6 to 15,730 for the infection rate and from 0 to 213 for the fatality rate. At this date, 1,766 municipalities had recorded no deaths (Table A3 in the Online Appendix). Simple correlations provide a first glimpse of the links between infection and death rates and the variables included in the analysis (Table 2). As expected, the infection rate depends on the test rate and the number of epidemic days in absolute terms and without lockdown $(0.31,0.32$ and 0.29$)$. It also depends on the rate of overcrowding in dwellings (0.38). Counterintuitively, it is negatively related to age $(-0.35)$ : the more young people there are in the municipality, the more the disease spreads. This correlation might stem from young people's lower level of compliance with restrictions and self-isolation measures contributing to an increase in infection rates. Of all the sociodemographic variables, the strongest correlation is observed for race $(-0.22$ for the proportion of whites in the municipality). The infection rate is also a function of poverty $(0.17) .^{23}$

With respect to the mortality rate, the correlations are generally of the same sign and the same order of magnitude as for the infection rate. Among the most striking results, mortality is a decreasing function of age $(-0.25)$. Mortality increases with density (0.21), as it does with work-related travel outside the municipality. Lastly, on the political front, the share of the president's supporters does not correlate with mortality, while it tends to lower the rate of infection.

The socioeconomic characteristics are themselves highly correlated with each other, in the expected direction and often at much higher levels. First, the share of the white population increases with higher education (0.52), municipality development (0.59), life expectancy (0.66) and age (0.70). On the political front, the share of whites increases with the vote for Bolsonaro (0.69). It is important to note these correlations between socioeconomic variables. Indeed, the simple (unconditional) correlations between Covid-19 indicators and these variables might ultimately merely reflect structural effects.

\section{Results and Discussion}

\section{The Basic Model}

Estimation covered different dates (from June to October), but we will mainly discuss the results for 11 August, date of the peak of the first wave in Brazil. A stepwise procedure, which adds sub-groups of our three blocks of variables (socioeconomic characteristics, transmission factors and policy responses) one by one until

\footnotetext{
23 The poverty rate is proxied by the rate of beneficiaries of the Auxilio Emergencial, the emergency aid reserved for poor families.
} 


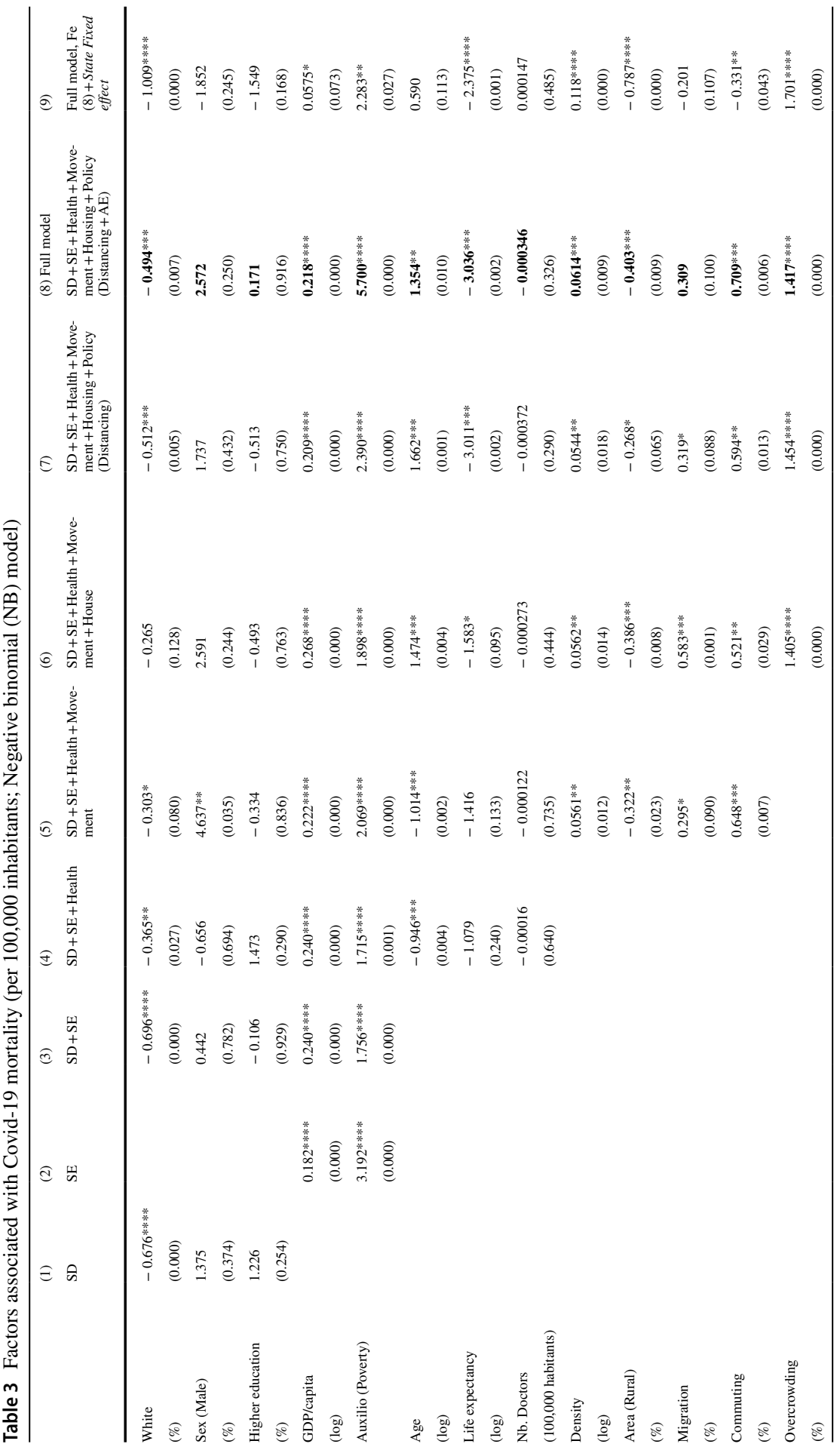

站。 


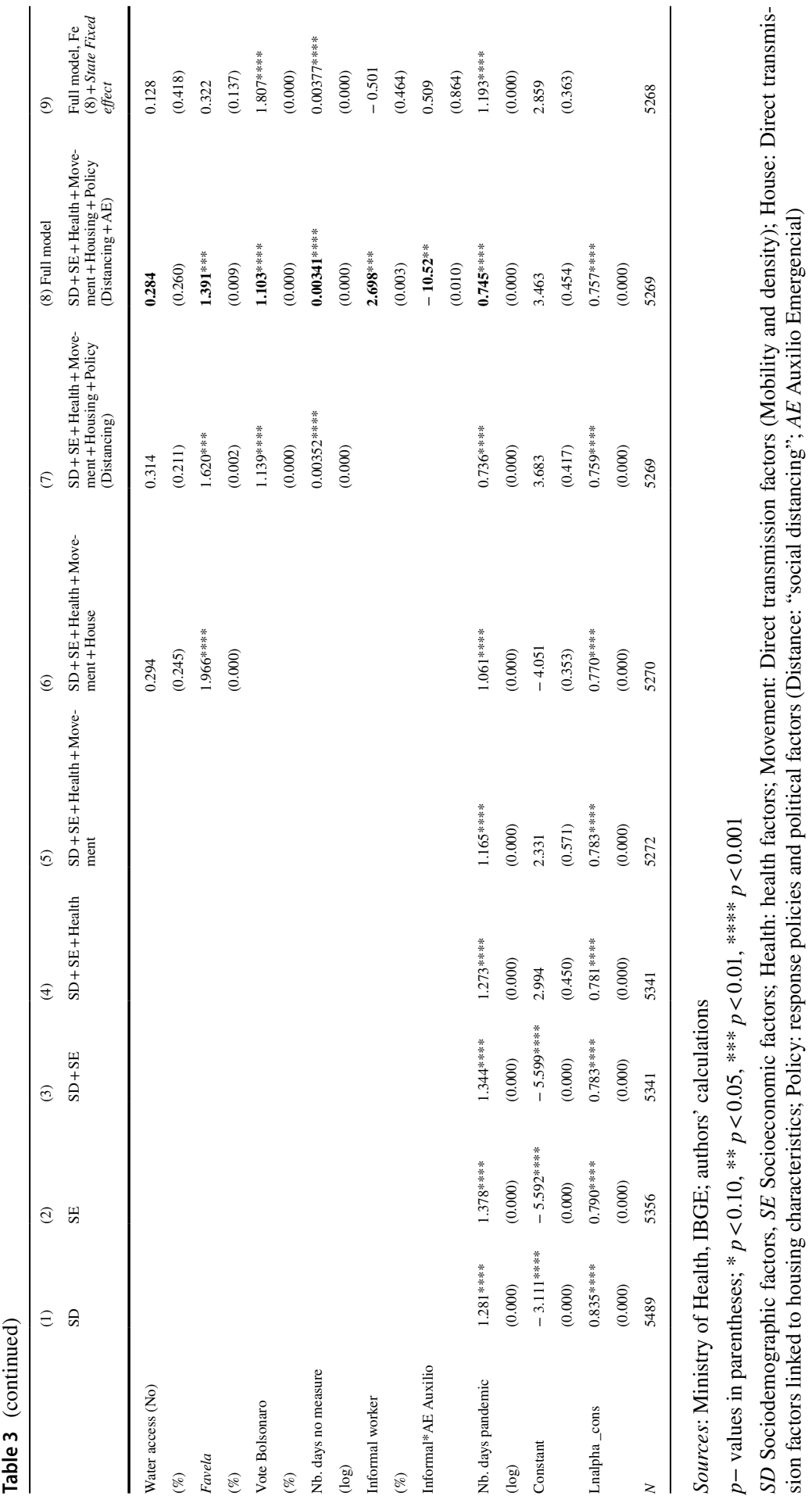


the model is complete, serves to assess the robustness of the effects (Table 3 and Table A4 in the Online Appendix). The results identify the main social groups at risk.

\section{Sociodemographic Indicators}

First, as expected, age matters. Municipalities where the population is older on average are harder hit in terms of deaths. However, municipalities with older people appear to have relatively fewer confirmed cases. Since this was initially neither the case in June nor in July (coefficients not significant), ${ }^{24}$ this change is compatible with the dynamics of the pandemic which is increasingly affecting young people. The gender effect is not really robust (coefficients not always significant), but tends to confirm that men are more at risk of Covid-19 infection and death. This result is in line with Griffith et al. (2020), who put forward a combination of epidemiological factors and social behaviour, with men tending to engage in more risky behaviour in general. Higher education has a negative effect on mortality and especially on confirmed cases. This result is especially robust in that this effect is a priori underestimated, as the more educated go to be tested more often. ${ }^{25}$ It could be suggested that this is due to better access to information and more careful behaviour. As regards racial disparities, municipalities with a higher percentage of whites are more likely to be spared, both in terms of confirmed cases and deaths. ${ }^{26}$ This is the most significant and robust effect of all our regressions. The size of the coefficient is far from negligible: an increase of 10 ppts in the proportion of whites in a municipality corresponds to a reduction by 1.1 in the mortality rate per 100,000 inhabitants, equivalent to a $5 \%$ decrease in the average death rate per municipality. The effect is especially striking in that it adds to the other aggravating factors included in the models from which non-white populations also suffer: a lower level of education, higher poverty rate, larger informal economy and poorer housing conditions (residence in favelas with more overcrowding, less access to public sanitation services), etc. ${ }^{27}$

\section{Health Status and Healthcare Infrastructures}

Logically speaking, longer average life expectancy, which can be interpreted as an overall health indicator (combined with the prevalence of comorbidity factors), reduces the death and infection rate in the municipality. Healthcare infrastructures as captured by the available indicators (presence of a state hospital, ratio of medical staff and number of beds) have no influence on either the presence of the disease or

\footnotetext{
${ }^{24}$ See Table 4 below and Table A5 in the Online Appendix.

25 The PNAD-Covid results show that the test rate increased with level of education in August from 4\% for those with no education or incomplete primary to $18 \%$ for those who had completed higher education (IBGE 2020; authors' calculations).

26 The PNAD-Covid results place the test rate slightly higher among whites (9\% in August) than among black and coloured people (8\%) (IBGE 2020; authors' calculations).

27 Similar results are found by a growing number of studies (see McLaren 2020, for example, for the US).
} 
the mortality rate. Some potential positive results (better patient care) might be offset by other negative effects (high level of infection among healthcare professionals; McLaren 2020).

\section{Economic Development and Poverty}

The most developed municipalities (measured by GDP per capita) are those with the highest rates of infection and mortality. Indeed, the epidemic started in the big cities (with the first cases recorded in São Paulo) and spread the fastest in these cities due to the intensity of social interactions (exchanges, population movements, diversity of economic and social activities). However, the higher the poverty incidence in the municipality, the harder it is hit (mortality and confirmed cases ${ }^{28}$ ). This result is consistent with a growing number of studies in other countries (Brandily et al. 2020). The conditional correlation coefficient is quite high: on average, an increase of 10 ppts in the poverty rate corresponds to $+77 \%$ more deaths. The equivalent figure for the number of cases is $+42 \%$. As the poverty effect holds when controlling for GDP per capita, our results suggest that the greater the inequalities, the higher the rate of infection and deaths.

\section{Density and Housing Conditions}

As expected, population density in the municipality is positively linked to the spread of the virus. Likewise, the coefficient for overcrowded housing is an aggravating factor. This result is also found for the death rate in France (Brandily et al. 2020). Conversely, living in rural areas lowers the rate of deaths and confirmed cases. On another note, the proportion of people living in favelas increases the impact of Covid-19. This effect transcends socioeconomic profile (poverty, health status, etc.), housing density and overcrowded dwellings, since these factors have already been taken into account. Neither is the "favela effect" a disguised impact of a lack of access to water and sanitation. We isolated the negative effect of no water access or sanitation on the infection rate (but not on mortality). We can therefore assume that the lack of access to basic services (excluding water services) penalises municipalities with a significant presence of favelas. The remarkable response of inhabitants and associations working in the favelas (Fiocruz 2020) has not been enough to cancel out the adverse effects of years of government underinvestment in these neighbourhoods.

\section{Mobility Indicators}

As expected, mobility indicators are positively correlated with the spread of the virus. The more mobile inhabitants are, the higher the rate of confirmed cases in a

\footnotetext{
${ }_{28}$ The effect is a conservative estimate for confirmed cases as the test rate increases with household income (from $7 \%$ for those earning less than half the minimum wage per capita to $22 \%$ for those earning more than four times the minimum wage; PNAD-Covid, August 2020).
} 
municipality. Infection rates are also higher in municipalities where workers have to travel outside the municipalities to their workplace.

\section{Labour Market and the Auxilio Emergencial}

The models show that the municipalities with the highest share of informal jobs have the highest infection and death rates.

This informality effect is important as a 10 ppt increase in informal jobs corresponds to $31 \%$ more deaths on average. ${ }^{29}$ This effect is not a disguised income effect, since the model controls for poverty. One of the possible explanations is that informal jobs are more exposed (roving vendors, street pitches, interactions with customers and fewer teleworking possibilities). ${ }^{30}$ Another explanation is that informal workers without access to welfare are forced to continue working and are therefore at a greater risk of infection (to themselves and others). However, the coefficient of the cross effect of informality and the Auxilio Emergencial is negative. It seems that informal workers have been able to reduce their structurally higher movements with the help of the emergency aid reserved for the poorest families. The protective effect of the $A E$ crossed with informality amounts to $21 \%$ fewer deaths on average for $\mathrm{a}+10 \mathrm{ppt}$ increase in beneficiaries of the cash transfer. This result suggests that the adverse effect of informality is partially offset by the $A E$.

\section{Measures and Socio-political Indicator}

First, regarding NPIs, the longer the time lag between the first confirmed case and population lockdown measures, the higher the infection and death rates. This result tends to confirm the effectiveness of restrictive measures. Second, the president's tactics to make light of the pandemic in his statements (uma gripezinha) and attitudes (participation in demonstrations and dismissing masks as protection) are major political factors. His supporters are consequently encouraged to ignore or comply less with measures designed to counter the disease. This might explain why, other things being equal, the municipalities where Bolsonaro obtained his best scores during the first round of the 2018 presidential election (the hard core of the president's supporters) are also harder hit, in a reversal of the initial negative correlation (Table 2). This sign change comes from the specific profile of the president's supporters: better off, more educated and more often white (Gomes de Souza 2018; Rennó 2018). The "Bolsonaro effect" is noticeable: 10 ppts more votes for the president correspond to $+12 \%$ more deaths on average (and $+11 \%$ more contamination). Our results are in line with other studies based on quasi-experimental approaches (Argentieri Mariani et al. 2020; Ajzenman et al. 2020) conducted in the early stages of the pandemic. Tentative evidence suggests that the Bolsonaro effect still holds in

\footnotetext{
${ }^{29}$ The distinction between formal and informal jobs appears to be more relevant compared with aggregate sector decomposition-primary, secondary and tertiary—which was tested, but with no significant impact.

30 See PNAD-Covid, August IBGE (2020).
}

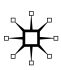


2021 (Rache et al. 2021). Similarly, a number of papers show that Republican supporters in the US respect social distancing measures less often (Allcott et al. 2020; Painter and Qiu 2020).

The specification with the state fixed effect (last column of Table 3 and Table A4 in the Online Appendix) serves to take into account common (or correlated) characteristics or actions by municipalities within a state and therefore to control for some possible omitted variables. However, this specification does not take into account dispersion between states and therefore conceals the potential effect of variables whose variability is relatively low within states (for example, the informality rate is higher and more homogeneous in the north-eastern states, and lower in the southern region). This may explain why, while most of the factors identified in the basic specification remain significant, the informality effect disappears when we introduce the state fixed effect.

\section{Robustness Checks}

Taking our study further, we estimated the full model at five different dates across the first wave of the pandemic: on 21 June when the milestone of one million confirmed cases was crossed, on 17 July when the two million mark was reached, and so on through to 11 October and five million cases. The corresponding figures for the number of deaths are 50,000,75,000, 100,000, 125,000 and 150,000. ${ }^{31}$ These estimates serve to both test the robustness of the results and track the progression of the pandemic over time. On the first point, while some coefficients vary from one period to the next, the vast majority of them maintain their sign and level of significance. The models are therefore very robust, with the different factors always in the same direction throughout the pandemic (Table 4 and Table A5 in the Online Appendix).

Below, we focus on four variables of interest (race, poverty, informality and Bolsonaro) to present the particularities of the Brazilian context. ${ }^{32}$ Regarding the relative magnitude of the risk factors between June and October, the panel regression with the interaction effect with time serves to assess how the coefficients change over time (see Tables A6 and A7 in the Online Appendix). If we assume that the coefficients change linearly over time, the effects of three of our four main variables of interest (race, poverty and informality) tend to diminish over time from the onset of the pandemic in the municipality. This may be due to different reasons: changing behaviour (the more vulnerable adjust their behaviour and become more careful) and, as the disease continues to spread, more and more population categories are infected. The Bolsonaro effect appears to be an exception since the coefficient

\footnotetext{
31 The precise figures are: $1,085,038 ; 2,046,328 ; 3,109,630 ; 4,041,638$ and 5,094,979 for the number of confirmed cases; and 50,617; 77,851; 103,026; 124,614 and 150,488 for the number of deaths (sources: Secretarias Estaduais de Saúde).

${ }^{32}$ Racial discrimination and inequalities are major issues in the country. In addition, analysis of the labour force survey (PNAD-Covid, IBGE, 2020) shows that informal workers were hard hit by the pandemic crisis. The cash transfer programme for informal workers moreover has extensive coverage. Last but not least, the effects of the president's attitude, a phenomenon which can hardly be ignored, need to be gauged.
} 
Table 4 Evolution of factors associated with the mortality rate over time (100,000 inhabitants; NB)

Death (date)

\begin{tabular}{lllll}
\hline 50,000 & 75,000 & 100,000 & 125,000 & 150,000
\end{tabular}

(21 June) (17 July) (11 August) (3 September) (11 October)

\begin{tabular}{|c|c|c|c|c|c|}
\hline Race (White) & $-0.48^{*}$ & $-0.59 * * *$ & $-0.49 * * *$ & $-0.50 * * *$ & $-0.59 * * * *$ \\
\hline Sex (Male) & $7.01 * *$ & $6.36^{* *}$ & $2.57 \mathrm{~ns}$ & $3.14 \mathrm{~ns}$ & $2.72 \mathrm{~ns}$ \\
\hline Higher education & $0.08 \mathrm{~ns}$ & $-0.51 \mathrm{~ns}$ & $0.17 \mathrm{~ns}$ & $0.24 \mathrm{~ns}$ & $0.42 \mathrm{~ns}$ \\
\hline GDP/cap (log) & $0.27 * * * *$ & $0.25 * * * *$ & $0.22 * * * *$ & $0.21 * * * *$ & $0.19 * * * *$ \\
\hline $\begin{array}{l}\text { Poverty (Auxilio Emerg. } \\
\text { (AE)) }\end{array}$ & $8.98 * * * *$ & $8.65 * * * *$ & $5.70 * * * *$ & $5.33 * * * *$ & $4.75 * * * *$ \\
\hline Age $(\log )$ & $4.20 * * * * *$ & $2.10 * * * *$ & $1.35 * *$ & $1.32 * * *$ & $1.98 * * * *$ \\
\hline Life Expectancy (log) & $-5.87 * * * *$ & $-3.86^{* * *}$ & $-3.04 * * *$ & $-2.03 * *$ & $-1.79 * *$ \\
\hline Nb. Doctors (100,000 inhab.) & $0.00 \mathrm{~ns}$ & $0.00 \mathrm{~ns}$ & $0.00 \mathrm{~ns}$ & $0.00 \mathrm{~ns}$ & $0.00 \mathrm{~ns}$ \\
\hline Density $(\log )$ & $0.07 * *$ & $0.08 * * *$ & $0.06 * * * *$ & $0.06^{* * *}$ & $0.05 * * *$ \\
\hline Area (Rural) & $-0.54 * *$ & $-0.67 * * * *$ & $-0.40 * * *$ & $-0.45^{* * * * *}$ & $-0.60 * * * *$ \\
\hline Migration & $0.51^{*}$ & $0.29 \mathrm{~ns}$ & $0.31 \mathrm{~ns}$ & $0.15 \mathrm{~ns}$ & $0.17 \mathrm{~ns}$ \\
\hline Commuting & $1.27 * * *$ & $0.64 * *$ & $0.71 * * *$ & $0.60 * * *$ & $0.56^{* * *}$ \\
\hline Overcrowding & $2.76 * * * *$ & $1.94 * * * *$ & $1.42 * * * *$ & $1.12 * * * *$ & $1.12 * * * *$ \\
\hline No Water Access & $0.74 * *$ & $0.18 \mathrm{~ns}$ & $0.28 \mathrm{~ns}$ & $0.14 \mathrm{~ns}$ & $0.00 \mathrm{~ns}$ \\
\hline Favela & $2.73 * * * *$ & $1.82 * * *$ & $1.39 * * *$ & $1.06 * *$ & $0.79 * *$ \\
\hline Vote for Bolsonaro & $0.53 \mathrm{~ns}$ & $0.62 * *$ & $1.10 * * * *$ & $1.13 * * * *$ & $1.19 * * * *$ \\
\hline $\mathrm{Nb}$. days without measure & $0.00 * * * *$ & $0.00 * * *$ & $0.00 * * * *$ & $0.00 * * * *$ & $0.00 * * *$ \\
\hline Informal worker & $5.02 * * * *$ & $4.84 * * * *$ & $2.70 * * *$ & $2.36 * * *$ & $2.00 * * * *$ \\
\hline $\begin{array}{l}\text { Informal * Auxilio Emer. } \\
\text { (AE) }\end{array}$ & $-20.89 * * * *$ & $-19.66^{* * * *}$ & $-10.52 * *$ & $-9.07 * *$ & $-6.85^{* *}$ \\
\hline Nb. days of Covid-19 & $0.76 * * * *$ & $0.91 * * * *$ & $0.75 * * * *$ & $0.84 * * * *$ & $1.03 * * * *$ \\
\hline Lnalpha_cons & $1.40 * * * *$ & $1.06 * * * *$ & $0.76 * * * *$ & $0.49 * * * *$ & $0.20 * * * *$ \\
\hline Nb. observations & 4818 & 5269 & 5269 & 5269 & 5258 \\
\hline
\end{tabular}

Negative Binomial (NB) model

Sources: Ministry of Health, IBGE, Facebook; authors' calculations. *p<0.10, *** $p<0.05 * * * p<0.01$, $* * * * p<0.001$

tends to increase over time. The observed increase in the Bolsonaro effect coefficient might be explained by the spread of the president's denialist narrative (which he continues to propagate, amplified by social media). Pro-Bolsonaro municipalities consequently contain less and less cautious people, as confirmed by Facebook Movement Range Maps. ${ }^{33}$ The Bolsonaro effect seems long lasting. Simple correlations computed by Rache et al. (2021)*** show that the acceleration in death rates was higher in pro-Bolsonaro municipalities from 2020 to 2021.

We conducted other robustness tests to consolidate our results in addition to the comparison of models over time presented above. The weak point in our analyses is

\footnotetext{
33 Figure available from the authors on request.
}

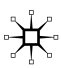


due to the fact that a certain number of socioeconomic variables are drawn from the 2010 population census (PC2010), the latest available in Brazil, while the country has seen some striking changes in the past decade. First, bear in mind that the time lag in the data is not a problem in that the relative ranking of municipalities has not changed substantially over time. However, there is good reason to think that most of the sociodemographic characteristics used in our models are structural features, which change only very slowly. To test this hypothesis, we compared how they had changed between previous PCs.

Table A8 (Online Appendix) shows the correlation between all available variables in the 1991, 2000 and 2010 census. Most of the correlations are very high (between 0.8 and 1), both between 2000 and 2010 and between 1991 and 2000. For instance, the average income per capita correlation stood at 0.92 between the last two PCs (2010 and 2000) and at 0.91 between 2000 and 1991. Over 20 years (1991-2010), the income correlation was as high as 0.86. This shows that the intermunicipality rankings have changed very little over time in terms of the main socioeconomic characteristics.

In the light of this, the situation is unlikely to have changed drastically between 2010 and 2020. In order to (partially) check this conclusion, we compared the results of the PC2010 with those of the PNAD-C 2019, the Brazilian Labour Force Survey. Given that the PNAD-C is not representative at municipal level, we computed the correlations at the most granular level available in the PNAD-C, namely the 74 geographic areas corresponding to the partition into three types of territories (capital, metropolitan region and others) at the level of the 27 States. Again, the correlations are high. We obtained the same result when we considered CAGED ${ }^{34}$ data on the percentage of formal workers. Therefore, although using the PC2010 data introduces some noise, it is likely to be limited and does not challenge our results.

Secondly, we tested numerous alternative specifications for our models (in log, weighted by the municipality population and in panels). ${ }^{35}$ All confirmed the robustness of our results. Different specifications were adopted for the estimation of the panel model. The first assumes that the effects of our main explanatory variables (constant over the period studied) do not change over time. Yet the results of the repeated cross-section approach appear to return changes for some coefficients. A second option takes into account a potential time trend. Lastly, a state fixed effect regression was also considered. Given the fact that many variables are constant over time, the coefficient for the factors not interacted with time becomes hard to interpret. However, for our main variables of interest, despite some slight changes in the level of the coefficients, overall, we obtained the same significant effects for our explanatory variables (Tables A6 and A7 in the Online Appendix). In addition, we substituted the variables with other alternative measures whenever these

\footnotetext{
34 CAGED data (General Register of Employed and Unemployed) records all formal workers (recruitments and dismissals).

35 Our study does not address the spatial spread of the pandemic, which calls for specific analyses. However, we also tested for spatial autocorrelations, which happen to be very low and are not likely to challenge our results.
} 
were available: for example, replacing GDP per capita with income per capita from PC2010; substituting different elements to capture the health system's characteristics (presence of state hospitals and number of ICU beds in the municipality); introducing the composite municipal human development index (IFDHM) developed by FIRJAN (2016) into the model, instead of the UNDP Human Development Index, along with its three sub-components instead of our education, health, and employment \& income variables. Here too, the results were borne out.

Lastly, in a certain number of (mainly developed) countries where the information is available, a measure of excess mortality is considered more reliable than official data on deaths due to Covid-19 (see Brandily et al. 2020, for example, for an application in the case of France). Note that this indicator is not without its issues (observed excess mortality is not necessarily due to Covid-19, the definition of the baseline is arbitrary, etc.) and above all depends on the quality of the mortality data (identification of cause of death, compilation of data, etc.). In Brazil, these conditions are not met: consolidated mortality data are not official until 2 years after they have been recorded (Marinho et al. 2020). The latest available official data today date back to 2018. After careful consideration of the micro-data, our own verdict is that the excess mortality data are less reliable than the official data on deaths due to Covid-19. Some studies comparing official data on Covid-19 deaths with excess mortality data for certain cities in Brazil (where the latter are less problematic) find relatively small differences compared with other countries. Although underestimation cannot be denied (França et al. 2020; Souza et al. 2020) and was estimated as potentially large in June (Veiga e Silva et al. 2020), the gap is decreasing over time (The Economist 2020).

Nevertheless, and despite these large gaps, we estimated excess mortality using different methodological options (comparing deaths in 2020 with the average for 2017 and $2018^{36}$ and for the previous 3 years, for the five months since January and for just the three months of March, April and May) based on the only available data (open data from the Ministry of Health). With all the reservations of rigour with respect to data quality, we re-estimated our model with this new measurement of the mortality rate. The results reveal much less explanatory power (Table A9 in the Online Appendix). However, the main variables of interest remain significant and with the same sign as in our basic model.

\section{Conclusion}

Three major conclusions can be drawn from this analysis. First, on the methodological front, we show the extent to which the approach at municipal level can provide relevant and consistent results. It is the only way to include the entire Brazilian population and all the country's regions in the analysis and, at the same time, make use of a wide range of available data sources. For example, we show the extent to

\footnotetext{
${ }^{36}$ For these 2 years, 2017 and 2018, the data are normally less subject to further corrections. However, the 2019 data cleaning and verification processes are not yet finished.
} 
which the expected "agglomeration effects" impact on infection and mortality rates. The most densely populated, urban municipalities with overcrowded housing pay a higher price. This result suggests that agglomeration prevention measures are key.

On the analytical front, the second main message supported by this study is that the Covid-19 pandemic has aggravated already huge socioeconomic inequalities in Brazil. Estimations made at different dates and using different specifications show that the risk of infection and death is higher for already disadvantaged groups. Such is the case for the poor, less educated, those with the shortest life expectancy, informal workers, those living in poor housing, those with difficulties accessing water and favela inhabitants. Although rich municipalities (with higher GDP per capita) have been harder hit, the positive correlation with the incidence of poverty suggests that the poor are more affected. Therefore, taking the interpretation further, it could be assumed that it is the poor in rich municipalities who are the most exposed. The gap between advantaged and disadvantaged individuals has been exacerbated by the pandemic. This result shows the importance of measures targeting specific fragile populations.

In addition, the study shows that, given equal conditions, municipalities with more whites have been the least hard hit. This result holds irrespective of the many control variables considered and, therefore, transcends the abovementioned vulnerability factors applying to non-white populations. This result could be due to other prevailing forms of discrimination, including unequal access to the health system.

The third message concerns the importance of policy responses: policy matters. Our results support the view that emergency aid has played a positive role. The Auxilio Emergencial has had a mitigating effect in locations where there are relatively more informal workers, enabling them to restrict commuting to work and thereby better protect themselves. We also highlight the influence of some specific measures. For example, our regression result is consistent with the assumption that the pandemic was brought more under control in municipalities where lockdown measures were taken sooner. Last but not least, the study shows that Covid-19 has caused more damage in more pro-Bolsonaro municipalities. The president's ambiguous rhetoric and attitudes may well have prompted his supporters to adopt more risky behaviour (less compliance with lockdown measures and the obligation to wear a mask in public spaces). Taking the interpretation further, this type of behaviour is detrimental not only at the individual level of the president's supporters, but more importantly it has wider repercussions at the collective level of the municipality. When the spread of the virus grows, paradoxically, the most disadvantaged social group — for example, the poor-who were less inclined to vote for Bolsonaro in 2018 are the hardest hit.

Supplementary Information The online version contains supplementary material available at https://oi. org/10.1057/s41287-021-00487-w. 


\section{References}

Ajzenman, N., T. Cavalcanti, and D. Da Mata. 2020. More than words leaders' speech and risky behavior during a pandemic. Cambridge working papers in economics, 2034, University of Cambridge.

Allcott, H., L. Boxell, J. Conway, M. Gentzkow, M. Thaler, and D.Y. Yang. 2020. Polarization and public health: Partisan differences in social distancing during the coronavirus pandemic. NBER working paper 26946.

Argentieri Mariani, L., J. Gagete-Miranda, and P. Rettl. 2020. Words can hurt: How political communication can change the pace of an epidemic. OSF. https://doi.org/10.31219/osf.io/ps $2 \mathrm{wx}$

Baqui, P.O., I. Bica, V. Marra, A. Ercole, and A. Van Der Schaar. 2020. Ethnic and regional variations in hospital mortality from COVID-19 in Brazil: A cross-sectional observational study. The Lancet Global Health 8: e1018-e1026. https://doi.org/10.1016/S2214-109X(20)30285-0.

Barberia, L., and E. Gómez. 2020. Political and institutional perils of Brazil's COVID-19 crisis. The Lancet 396: 367-368.

Bartholo, L., A. Paiva, M. Natalino, E. Licio, and M. Pinheiro. 2020. As transferências monetárias federais de caráter assistencial em resposta à COVID-19: Mudanças e desafios de implementação. Nota Técnica n. 72 (Disoc), IPEA.

Batista, A., B.Antunes, G. Faveret, I. Peres, J. Marchesi, J.P. Cunha, L. Dantas, L. Bastos, L. Carrilho, S. Aguilar, F. Baião, P. Maçaira, S. Hamacher, and F. Bozza. 2020. Análise socioeconômica da taxa de letalidade da COVID-19 no Brasil. Núcleo de Operações e Inteligência em Saúde (NOIS), Nota Técnica 11.

Benítez, M.A., C. Velasco, A.R. Sequeira, J. Henríquez, F.M. Menezes, and F. Paolucci. 2020. Responses to COVID-19 in five Latin American countries. Health Policy and Technology 9 (4): 525-559.

Braga Ribeiro, K., A. Freitas Ribeiro, M.A. Veras, and M. de Castro. 2021. Social inequalities and COVID-19 mortality in the city of São Paulo, Brazil. International Journal of Epidemiology 50: $732-742$.

Brandily, P., C. Brébion, S. Briole, and L. Khoury. 2020. A poorly understood disease? The unequal distribution of excess mortality due to COVID-19 across French municipalities. MedRxiv. https://doi. org/10.1101/2020.07.09.20149955.

Brodeur, A., D. Gray, D. Islam, and S.J. Bhuiyan. 2020. A literature review of the economics of Covid. IZA Discussion paper series, 13411

Brown, C., and M. Ravallion. 2020. Inequality and the coronavirus: Socioeconomic covariates of behavioral responses and viral outcomes across US counties. NBER working paper 27549 (2020)

Carvalho, S.S.D. 2020. Os efeitos da pandemia sobre os rendimentos do trabalho e o impacto do auxílio emergencial: o que dizem os microdados da PNAD Covid-19. Carta de Conjuntura 4, Mercado de Trabalho. $3^{\circ}$ trimestre de 2020.

Carvalho, S. 2021. Retrato dos rendimentos e horas trabalhadas durante a pandemia - Resultados da PNAD Contínua em 2020. Carta de Conjuntura n. 51. Nota de Conjuntura 4. $2^{\circ}$ trimestre.

Costa, J., and M. Reis. 2020.: Uma análise da MP n ${ }^{\circ}$ 936/2020 sobre os rendimentos dos trabalhadores e a renda domiciliar per capita. Nota Técnica $\mathrm{n}^{\circ} 71$, DISSOC/IPEA.

De Negri, F., R. Galliez, P. Miranda, P. Koeller, G. Zucoloto, J. Costa, C. de Farias, G. Travassos, and R. Medronho. 2020. Aspectos socioeconômicos da COVID-19: Chances de Óbito por Covid-19 Entre Os Trabalhadores Formais: Evidências do Estado do Rio de Janeiro. IPEA, Nota Técnica, Diset 76.

França, E.B., L.H. Ishitani, R.A. Teixeira, D.M.X. Abreu, P.R. Corrêa, F. Marinho, and A.M. Vasconcelos. 2020. Deaths due to COVID-19 in Brazil: how many are there and which are being identified? Revista Brasileira De Epidemiológia 23: e200053. https://doi.org/10.1590/1980-549720200053.

Fiocruz: Boletim socioepidemiológico da Covid-19 nas Favelas. 1, Rio de Janeiro, (2020)

FIRJAN: Índice Firjan de Desenvolvimento Municipal (IFDM) - Ano base 2016. Pesquisa e estudos socioeconômicos, FIRJAN, July, 2018.

Fonseca, E., N. Nattrass, and F. Bastos. 2020. COVID-19 in Brazil: Presidential denialism and the subnational government's response. https://doi.org/10.13140/RG.2.2.36418.81609.

Gomes de Souza, H., C.Araujo, G. Barbosa, and A. Almeida. 2019. Quais fatores foram determinantes no resultado da eleição présidenticial brasileira en 2018. Anpec.

Griffith, D.M., G. Sharma, C.S. Holliday, O.K. Enyia, M. Valliere, A.R. Semlow, et al. 2020. Men and COVID-19: A biopsychosocial approach to understanding sex differences in mortality and recommendations for practice and policy interventions. Preventing Chronic Disease 17: 200247. https:// doi.org/10.5888/pcd17.200247(2020). 
Hallal, P.C., F.P. Hartwig, B.L. Horta, M.F. Silveira, C.J. Struchiner, L.P. Vidaletti, N.A. Neumann, L.C. Pellanda, O.A. Dellagostin, M.N. Burattini, G.D. Victora, A.M.B. Menezes, F.C. Barros, A.J.D. Barros, and C.G. Victora. 2020. SARS-CoV-2 antibody prevalence in Brazil: Results from two successive nationwide serological household surveys. Lancet Global Health 8 (11): e1390-1398. https://doi.org/10.1016/S2214-109X(20)30387-9.

Hecksher, M., and M. Foguel. 2020. Benefícios emergenciais aos trabalhadores informais e formais no Brasil: Estimativas das taxas de cobertura combinadas da lei no 13.982/2020 e da Medida Provisória $\mathrm{n}^{\circ}$ 936/2020. Nota Técnica ${ }^{\circ} 66$, DISSOC/IPEA

IBGE. 2012. Censo demográfico 2010 : Resultados gerais da amostra. Rio de Janeiro: IBGE.

IBGE. 2013. Pesquisa nacional de saúde 2013. Rio de Janeiro: IBGE.

IBGE. 2018. Perfil dos municípios brasileiros: 2018. Rio de Janeiro: IBGE.

IBGE. 2020. PNAD-Covid: 2020. Rio de Janeiro: IBGE.

Instituto Polis. 2020. Raça e Covid no município de São Paulo. https://polis.org.br/estudos/ raca-e-covid-no-msp/.

International Monetary Fund. 2020. Fiscal monitor-Policies to support people during the COVID-19 pandemic. Washington, DC: IMF.

Lameiras, M. 2021. Desempenho recente do mercado de trabalho e perspectivas para o ano. Carta de Conjuntura n. 51. Nota de Conjuntura 6. $2^{\circ}$ trimestre.

Lasco, G. 2020. Medical populism and the COVID-19 pandemic. Global Public Health 15 (10): 1417-1429.

Malta, M., L. Murray, C. da Silva, and S. Strathdee. 2020. Coronavirus in Brazil: the heavy weight of inequality and unsound leadership. EClinicalMedicine 25: 100472.

Marinho, F., A. Torrens, R. Teixeira, E. França, A.M. Nogales, D. Xavier, and T. Fujiwara. 2020. Excess mortality in Brazil: Detailed description of trends in mortality during the COVID-19 pandemic. Vital Strategies, Technical Note.

Mattei, L., and V. Heinen. 2020. Impacts of the COVID-19 Crisis on the Brazilian Labor Market. Brazilian Journal of Political Economy 40 (4): 647-668.

Menezes-Filho, N., B. Komatsu, and J. Rosa. 2021. Reducing poverty and inequality during the coronavirus outbreak: The emergency aid transfers in Brazil. Policy Paper n. 54, Insper.

McLaren, J. 2020. Racial disparity in COVID-19 death: Seeking economic roots with Census data. NBER Working Paper 27407 [http://www.nber.org/papers/w27407].

Miranda, P., P. Koeller, G. Zucoloto, W. Machado, and F. De Negri. 2020. Aspectos socioeconômi$\cos$ da COVID-19: o que dizem os dados do Município do Rio de Janeiro?. IPEA, Nota Técnica, Diste 72.

Moraes, R.F., L.L.S. Silva, and C.M. Toscano. 2020. Covid-19 e Medidas de Distanciamento Social no Brasil: Análise Comparativa dos Planos Estaduais de Flexibilização. Nota Técnica - Número 25 - Dinte/IPEA.

Nassif-Pires, L., L. Carvalho, and E. Hawet. 2020a. Multidimensional inequality and covid-19 in Brazil. Levy Economics Institute of Bard College, Public Policy Brief, 153.

Nassif-Pires, L., L. Xavier, T. Masterson, M. Nikiforos, and F. Rios-Avila. 2020b. Pandemic of Inequality. Levy Economics Institute of Bard College, Public Policy Brief 149.

Nunes, L., R. Rocha, and G. Ulyssea. 2020. Vulnerabilidades da População Brasileira à COVID-19: Desafios para a Flexibilização do Distanciamento Social. Instituto de Estudos para Políticas de Saúde, Nota Técnica no. 9.

Ortega, F., and M. Orsini. 2020. Governing COVID-19 without government in Brazil: Ignorance, neoliberal authoritarianism, and the collapse of public health leadership. Global Public Health 15 (9): 1257-1277.

Paim, J., C. Travassos, C. Almeida, L. Bahia, and J. Macinko. 2011. The Brazilian health system: History, advances, and challenges. The Lancet 377 (9779): 1778-1797.

Painter, M.O., and T. Qiu. 2020. Political beliefs affect compliance with COVID-19 social distancing orders. https://doi.org/10.2139/ssrn.3569098.

Pereira, A., M. Oliveira, and T. Sampaio. 2020. Asymmetries of state government social distancing policies in the face of COVID-19: Political and technical-administrative aspects. Revista De Administração Pública 54 (4): 678-696.

Rache, B., M. Lago, F. Falbel, and R. Rocha. 2021. Quantas Vidas Cabem em um Voto?. Instituto de Estudos para Políticas de Saúde (IEPS), Nota Técnica ${ }^{\circ} 18$, São Paulo.

Rennó, L.R. 2020. The Bolsonaro voter: Issue positions and vote choice in the 2018 Brazilian presidential elections. Latin American Politics and Society, 1-23, Ses. 
Ricard, J., and J. Medeiros. 2020. Using misinformation as a political weapon: COVID-19 and Bolsonaro in Brazil. The Harvard Kennedy School (HKS) Misinformation Review 1(2): 1-6

Rocha, R., R. Atun, A. Massuda, B. Rache, P. Spinola, L. Nunes, M. Lago, and M.C. Castro. 2021. Effect of socioeconomic inequalities and vulnerabilities on health-system preparedness and response to COVID-19 in Brazil: a comprehensive analysis. Lancet Global Health. https://doi.org/10.1016/ S2214-109X(21)00081-4.

Silva, M. S. 2020. Política Econômica Emergencial Orientada para a Redução dos Impactos da Pandemia da Covid-19 no Brasil: medidas fiscais, de provisão de liquidez e de liberação de capital. Discussion Paper 2576, IPEA.

Silveira, M.F., A.J.D. Barros, B.L. Horta, L. Pellanda, G. Victora, O.A. Dell'Agostin, C. Struchiner, M. Burattini, A. Valim, E. Berlezi, J. Mesa, M. Ikeda, M. Mesenburg, M. Mantesso, M. Dallagnol, R. Bittencourt, F. Hartwig, A. Menezes, C. Fernando, F. Barros, P. Hallal, and C. Victora. 2020. Population-based surveys of antibodies against SARS-CoV-2 in Southern Brazil. Nature Medicine 26: 1196-1199. https://doi.org/10.1038/s41591-020-0992-3.

Souza, W.M., L.F. Buss, D. da Silva Candido, J.-P. Carrera, S. Li, A.E. Zarebski, R.H.M. Pereira, C.A. Prete, A.A. de Souza-Santos, K.V. Parag, et al. 2020. Epidemiological and clinical characteristics of the covid-19 epidemic in Brazil. Nature Human Behaviour 4: 856-865.

Tavares, F., and G. Betti. 2020. Vulnerability, poverty and COVID-19: Risk factors and deprivations in Brazil. World Development, Forthcoming.

The Economist. 2020. Covid-19 data: Tracking covid-19 excess deaths across countries, https://www. economist.com/graphic-detail/2020/07/15/tracking-covid-19-excess-deaths-across-countries. Update (October 14th 2020).

Veiga e Silva, L., M. Da Penha de Andrade Abi Harb, A. Teixeira Barbosa dos Santos, C. de Mattos Teixeira, V. Macedo Gomes, E. Silva Cardoso, M. da Silva, N. Vijaykumar, S. Venâncio Carvalho, A. Ponce de Leon Ferreira, and C. Lisboa Frances. 2020. COVID-19 mortality underreporting in Brazil: Analysis of data from government internet portals. Journal of Medical Internet Research 22(8): e21413. https://doi.org/10.2196/21413.

Waltenberg, F., J. Lago da Silva, and R. Carvalho da Silva. 2020. Abono Salarial Emergencial para apoiar trabalhadores formais de baixa renda. Discussion Paper n. 150, Center for Studies on Inequality and Development, Economics Institute, UFRJ.

World Bank. 2020. The economy in the time of Covid-19. LAC Semiannual Report. Washington, DC: World Bank. [https://openknowledge.worldbank.org/handle/10986/33555.

Publisher's Note Springer Nature remains neutral with regard to jurisdictional claims in published maps and institutional affiliations. 